\title{
( \\ UTILIZATION OF MARBLE WASTE IN LIGHTWEIGHT CONCRETE REPLACING FINE AGGREGATES: A REVIEW
}

\section{Mauli G. Joshi \\ Dr. Jayeshkumar R. Pitroda*}

Final Year M.Tech Construction Project Management Student, Parul University, Limda, Vadodara

\section{ABSTRACT}

Associate Professor, Civil Engineering Department, BVM Engineering College, Vallabh Vidyanagar, Anand *Corresponding Author $30 \%$ during cutting process. This study deals with reviewing the use of waste from marble industry in light-weight aggregate and the effect on fresh and hardened concrete properties. Light weight concrete reduce DL and overall cost as compare to concrete. These are basically cold materials which will helps to decrease Indore temp.Waste material utilization helps to maintain cleanliness. Lightweight concrete is porous which helps to control flood water and also the earthquake damage due to its light self-weight.

KEYWORDS : Waste, marble Industry, lightweight concrete, Economical

\section{INTRODUCTION:}

Structural lightweight concrete has superior properties that allow the optimization of super tall structure systems for the process of design. Compared to normal and heavyweight concrete, structural lightweight concrete has the Advantage of having a finer density. Lightweight concrete composite were used successfully for many years for structural members and Elements in The production of stable foam concrete mix depends on many factors such as selection of foaming agent, method of foam preparation and addition for uniform air voids distribution, materials section and mixture design strategies, production of foam concrete and performance with respect to fresh and hardened state are of greater significance. In addition to its lighter weight, which Permits saving in dead load and so reduces the cost of both super structure and foundations.

\section{Critical Literature Review}

\subsubsection{Lightweight concrete with Marble Waste :}

Ronak Malpani (2014) had done Partial Replacement to examine Effect of Marble Sludge Powder and Quarry Rock Dust as for Fine Aggregates on Properties of Concrete according to him Use of alternate aggregate materials has greater potential because $75 \%$ of concrete is composed of aggregates. His experimental study had been observed that particular proportions of marble sludge powder and quarry rock dust displayed enhancing effect on the compressive strength.(1)

Kore S.D. (2016) completed his research on Durability of concrete using marble mining waste he fixed the water-cement ratio at 0.45 for all the mixes. His Overall the results supported by microstructure analysis which indicates that there is no significant adverse effect on the use of marble waste as a coarse aggregate on the durability properties of concrete. The results of fire study reveal that, concrete with marble waste performs better than control concrete. (2)

Dr.Ishwar Chand Sharma (2015) studied on use of Marble Slurry In Cement Concrete Replacing Fine Aggregate he analyzed Different properties of marble slurry determined in the laboratory having $\mathrm{Sp}$. gravity 2.61, Fineness modulus was found to be 0.91 and Utilization of marble slurry in Cement Concrete replacing Sand is 30\% which was seem equal strength as of Control And finalized that Marble slurry can be easily utilized in construction industry in preparing Cement Concrete.(3)

Piyush Singh (2018) had done different Experimental study on effect of partial replacement of marble dust on concrete with M30 grade of cement with the addition of coconut coir he investigated this research to find materials to replace concrete by partially. He took the waste materials from industry like marble dust and coconut coir. And finalized results by showing the strength of concrete with different variation of percentage. (4)

Bhupendra Singh (2015) Studied on Concrete Using Marble Powder Waste as Partial Replacement of Sand The main objective of his research was to explore the possibility of using marble powder waste as partial replacement of fine aggregate in concrete. Concrete was prepared in four different proportions and tested for the period of 7 days, 28days, 90days curing. This compressive strength compared with the conventional concrete. (5)

Debasmita Panda (2017) Analyzed on Mix Design of High Strength Concrete (HSC) using IS: 10262-1982 and partial replacement of waste marble aggregates as coarse aggregate her research include the mix design of high strength concrete (HSC) concrete having specified characteristic compressive strength of $60 \mathrm{Nmm} 2 /$. She was successfully proved that High strength concrete was a construction material with improved properties like strength, durability etc. than ordinary concrete and completed her work with Conclusion that High strength concrete can be achieved through proper mix design process. (6)

P.A. Shirulea (2012) researched on Partial replacement of cement with marble dust powder he found the Marble Stone slurry generated during processing corresponds to around $40 \%$ of the final product from stone industry. His research was related to the stone industry present an annual output of 68 million tons of processed products. He also observed that there are several reuse and recycling solutions for this industrial by-product, both at an experimental phase and in practical applications and those industrial wastes are dumped in the nearby land and the natural fertility of the soil is spoiled. (7)

Sudarshan (2016) done the Cost Effective Design of Sustainable Concrete Using Marble Waste as Coarse Aggregate. After experimental study he observed that Influence of coarse aggregate produced from marble waste on the mechanical and durability properties of concrete mixes were studied. The results of abrasion test seems that, the concrete produced using marble aggregate can be used in pavement works. And also found the Resistance to acid of concrete containing marble waste was marginally low as compared to that of control concrete. (8)

Salim (2016) give his opinion on Compressive Strength and Abrasion Resistance of Concrete with the use of Waste Marble and Demolition Aggregate he predict the effect of waste materials on engineering properties of concrete and Results of his paper proved that waste marble residue and demolition waste are the best alternatives for concrete production to eliminate natural hazard of waste materials in environment for sustainability. He also proves that because adding these kind of materials keeps the properties of concrete either constant or develop. (9)

Vyas A. K. (2016) worked on Performance Evaluation of Concrete using Marble Mining Waste, in which the impact of marble aggregate on the mechanical properties of concrete was studied. From his results it can be concluded that, the water absorption of the mix containing marble aggregate was reduced by $17 \%$ and permeability reduced by $7 \%$, for improvement in durability performance of concrete. The Ultra Sonic pulse velocity values show that, the partial 
Volume-10 | Issue-2 | February - 2020 | PRINT ISSN No. 2249 - 555X | DOI : 10.36106/ijar

replacement of conventional coarse aggregate by marble aggregate results in dense, homogeneous and uniform structure of concrete it was indicated that, the marble aggregate can be used to improve the mechanical properties of concrete. (10)

Table 1: Chemical Properties of industrial wastes

\begin{tabular}{|c|c|c|c|c|c|c|c|c|}
\hline \multirow{3}{*}{$\begin{array}{c}\text { Chemical properties } \\
(\%)\end{array}$} & \multicolumn{8}{|c|}{ Author / Materials } \\
\hline & Javad (2015) & $\begin{array}{l}\text { Payam } \\
(2014)\end{array}$ & Hilmi (2016) & Shahul (2010) & Sekar (2016) & $\begin{array}{c}\text { Hameed } \\
(2017)\end{array}$ & $\begin{array}{l}\text { Dinakar } \\
(2013)\end{array}$ & $\begin{array}{c}\text { Manu S. } \\
(2015)\end{array}$ \\
\hline & $\mathrm{OPC}$ & $\begin{array}{l}\text { Fly Ash } \\
\text { (FA) }\end{array}$ & $\begin{array}{c}\text { Rice } \\
\text { Husk Ash (RHA) }\end{array}$ & $\begin{array}{c}\text { Marble sludge } \\
\text { powder }\end{array}$ & River sand & Quarry Dust & $\begin{array}{l}\text { Portland } \\
\text { cement }\end{array}$ & Cement \\
\hline $\mathrm{SiO}_{2}$ & 16.68 & 50.24 & 91.02 & 64.84 & 75.25 & 80.78 & 21.50 & 21.35 \\
\hline $\mathrm{Fe}_{2} \mathrm{O}_{3}$ & 3.64 & 10.37 & 1.19 & 11.99 & 1.22 & 1.75 & 0.55 & 2.60 \\
\hline $\mathrm{Al}_{2} \mathrm{O}_{3}$ & 4.41 & 23.53 & 0.30 & 4.45 & 13.63 & 10.52 & 5.50 & 5.80 \\
\hline $\mathrm{CaO}$ & 68.36 & 6.95 & 0.80 & 1.58 & 1.28 & 3.21 & 63.50 & 62.30 \\
\hline $\mathrm{MgO}$ & 1.29 & 1.84 & 0.90 & 8.74 & 0.33 & 0.77 & 2.15 & 3.33 \\
\hline $\mathrm{SO}_{3}$ & 4.80 & 6.94 & 0.30 & - & - & - & - & 2.50 \\
\hline $\mathrm{K}_{2} \mathrm{O}$ & 0.36 & 1.53 & 3.17 & 2.33 & 5.34 & 1.23 & 0.85 & - \\
\hline $\mathrm{Na}_{2} \mathrm{O}$ & - & - & - & 2.08 & 3.0 & 1.35 & 0.85 & - \\
\hline LOI & 1.42 & 5.9 & 1.4 & - & - & - & - & - \\
\hline
\end{tabular}

The following table 2 shows the literature review papers based on cement replacement by marble waste and its Comparison.

Table 2: literature review papers based on cement replacement by Marble waste powder with light weight aggregate and it's Comparison

\begin{tabular}{|c|c|c|c|c|c|c|c|c|}
\hline \multirow{2}{*}{$\begin{array}{l}\text { Sr. } \\
\text { No. }\end{array}$} & \multirow[t]{2}{*}{ Author Name } & \multirow[t]{3}{*}{ Particle Size } & \multicolumn{4}{|c|}{ Prime Constituents in marble waste } & \multirow{2}{*}{\multicolumn{2}{|c|}{$\begin{array}{c}\text { Grade of Concrete } \\
\text { Optimum \%age Replacement }\end{array}$}} \\
\hline & & & $\mathrm{SiO}_{2}$ & $\mathrm{Al}_{2} \mathrm{O}_{3}$ & $\mathrm{Fe}_{2} \mathrm{O}_{3}$ & $\mathrm{CaO}$ & & \\
\hline 1 & Sekar (2016) & & $21.77 \%$ & $2.59 \%$ & $0.65 \%$ & $57.02 \%$ & & \\
\hline 2 & Shahul (2010) & $1.18 \mathrm{~mm}$ & $51.7 \%$ & $18.2 \%$ & $6.1 \%$ & $6.1 \%$ & M30 & $15 \%$ \\
\hline 3 & Hilmi (2016) & $2.36 \mathrm{~mm}$ & $63.29 \%$ & $18.29 \%$ & $4.32 \%$ & $4.46 \%$ & M20 & $30 \%$ \\
\hline 4 & Javad (2015) & $4.75 \mathrm{~mm}$ & $60.21 \%$ & $32.43 \%$ & $1.152 \%$ & $2.16 \%$ & M35 & $25 \%$ \\
\hline 5 & Shahul (2010) & $10 \mathrm{~mm}$ & $68.8 \%$ & $18.4 \%$ & $4.6 \%$ & $1.5 \%$ & M35 & $20 \%$ \\
\hline 6 & Payam (2014) & $75 \mu \mathrm{m}$ & $63.29 \%$ & $18.29 \%$ & $4.32 \%$ & $4.46 \%$ & M20 & $30 \%$ \\
\hline 7 & vyas (2016) & $150 \mu \mathrm{m}$ & $51.04 \%$ & $43.42 \%$ & $0.52 \%$ & $0.18 \%$ & M20 & $25 \%$ \\
\hline 8 & sudershan (2016) & $300 \mu \mathrm{m}$ & $63.29 \%$ & $18.29 \%$ & $4.32 \%$ & $4.46 \%$ & M30 & $10 \%$ \\
\hline 9 & Sudarshan. (2017) & $600 \mu \mathrm{m}$ & $51.7 \%$ & $18.34 \%$ & $6.35 \%$ & $6.21 \%$ & M30 & $15 \%$ \\
\hline
\end{tabular}

The following table 3 shows the literature review papers based on cement and fine aggregate replacement by waste and it's Comparison.

Table 3: Literature Review Papers and its Comparison

\begin{tabular}{|c|c|c|c|c|c|c|}
\hline No. & Year & Utilization Area & Material Used & Addition/ Replacement & Test & Increase/ Decrease \\
\hline 1 & Sekar (2016) & cement & OPC & Replacement & Compressive Strength & Increase \\
\hline 2 & Javad (2015) & fine aggregate & Marble sludge powder & Replacement & Compressive Strength & Increase \\
\hline 3 & Shahul (2010) & Cement & River sand & Replacement & Compressive Strength & Increase \\
\hline 4 & Payam (2014) & OPC & Quarry Dust & Replacement & Compressive Strength & Increase \\
\hline 5 & sudershan (2016) & Fine aggregate & Cement & Replacement & Compressive Strength & Increase \\
\hline
\end{tabular}

\section{Major Finding from the Critical Literature Reviews:}

1) Workability, adsorption of durability and permeability of lightweight concrete increases with the use of clay west in LWC mix.

2) When concrete containing marble aggregate it shows marginally better performance as comparing to the control concrete when concrete is supposed to sulphates.

3) Reduction of permeability by $8 \%$ of concrete produced using marble mining waste is the indication for batter durability in the future.

4) The marble slurry shows good and acceptable strength when added in cement mortar and cement concrete both.it can be used as filler material with replacement of $30 \%$ of sand by showing same strength.

\section{CONCLUSION}

Based on critical literature review, following conclusions are been made:

1) Use of coir fibre increases the ass of concrete and decreases strength of concrete because they are majorly affects the properties of concrete.

2) Structural lightweight concrete can be made with normal coarse aggregates and formal agent

3) The marble waste can be the replacement of any prime constituents of the concrete like cement coarse aggregate and fine aggregate/sand.

4) The compressive strength test is mostly adopted and widely used test for checking the concrete parameter.

5) The range effective replacement of cement with marble waste powder in concrete lies between $35-50 \%$ and it gets decreases as the grade of concrete increases.

6) Overall review study shows that waste marble powder and marble slurry can be used in lightweight aggregate without any adverse effect in environment or in concrete mix

\section{REFERENCES:}

(1) Ronak Malpani, Sachith Kumar Jegarkal (June 2014). "Effect of Marble Sludge Powder and Quarry Rock Dust as Partial Replacement for Fine Aggregates" Vol. 2, Issue 5.

(2) Kore S.D., Vyas A.K. on (November 2016)."Durability of concrete using marble mining waste" Article ID 626425

(3) Er: Raj.p.singh kushwah1, Prof (Dr.) Ishwar Chand Sharma2, Prof (Dr.) PBL Chaurasia3 (2014) Utilization of "Marble Slurry" In Cement Concrete Replacing Fine aggragates."- Hindawi Publishing Corporation Advances in Materials Science and Engineering Volume-2.

(4) Piyush Singh Tekaley, Dr. Ashutosh S Trivedi -march (2018). "Experimental study on effect of partial replacement of marble dust on concrete M30 with the addition of coconut coir. Science direct.

(5) Bhupendra Singh Kalchuri1, Dr. Rajeev Chandak2, R.K.Yadav April 2015 "Study on Concrete Using Marble Powder Waste As Partial Replacement Of Sand.” April 2015 , Vol. 3, Issue 06

(6) Debasmita Panda*, Dr. (Prof.) P.K. Parhi June 2017 “Analysis on Mix Design of High Strength Concrete (HSC) using IS: 10262-1982

(7) Prof. P.A. Shirulea, Ataur Rahmanb, Rakesh D. Guptac April-June, 2012 "Partial replacement of cement with marble dust powder" Vol. 3, Issue 06

(8) Sudarshan D. Kore , A. K. Vyas -june2016 "Cost Effective Design of Sustainable Concrete Using Marble Waste as Coarse Aggregate" in -JOURNAL OF MATERIALS AND ENGINEERING STRUCTURES.

(9) Selim Cemalgil, Onur Onat - (2016) “Compressive Strength and Abrasion Resistance of Concrete with Waste Marble and Demolition Aggregate" IS: 10262-

(10) Kore Sudarshan Dattatraya and Vyas A. K. (2015) "Performance Evaluation of Concrete using Marble Mining Waste”2016. Vol. 3, Issue 06. 